\title{
UJI AKTIVITAS ANTIOKSIDAN EKSTRAK ETANOL BULBUS BAWANG DAYAK (Eleutherine americana Merr) DENGAN METODE DPPH (1,1-Diphenyl-2-Picrylhydrazyl)
}

\section{ANTIOXIDANT ACTIVITY TEST OF ETHANOL EXTRACTS DAYAK ONION BULBS (Eleutherine americana Merr) WITH DPPH METHOD (1,1-Diphenyl-2-Picrylhydrazyl).}

\author{
Rizkah V. Mokoginta ${ }^{1)^{*}}$, Herny E. I. Simbala ${ }^{1)}$, Karlah L. R. Mansauda ${ }^{1)}$ \\ ${ }^{1)}$ Program Studi Farmasi FMIPA UNSRAT Manado, 95115 \\ *rzkvelonia@gmail.com
}

\begin{abstract}
Dayak onion plant (Eleutherine americana Merr.) or commonly called forest onion is a typical plant of Central Kalimantan that has been used by local peoples for cure a various types of diseases. This study aims to determine the activity of antioxidant compounds from Dayak bulb ethanol extracts from Kotamobagu City. This research method is an experimental laboratory. Initially the Dayak bulb sample was extracted maceration with $96 \%$ ethanol solvent then evaporated until a thick extract was obtained. As a parameter, the DPPH method (1,1-diphenyl-2-picrylhydrazyl) was used to test the antioxidant activity of the samples at concentrations of 50,60,70, 80 and $90 \mathrm{mg} / \mathrm{L}$ and as a comparison standard used Vitamin $C$ with concentrations of 2, 4, 6, 8 and $10 \mathrm{mg} / \mathrm{L}$. The results obtained showed antioxidant activity in Dayak bulb ethanol extracts with $I C_{50}$ values of $41.46 \mathrm{mg} / \mathrm{L}$ and on vitamin $C I C_{50}$ values of $1.04 \mathrm{mg} / \mathrm{L}$. Based on these results it can be concluded that the onion bulb ethanol extract has very strong antioxidant activity.
\end{abstract}

Keywords: Dayak Onion bulbs, Activity, Antioxidant, DPPH

\begin{abstract}
ABSTRAK
Tanaman bawang Dayak (Eleutherine americana Merr.) atau biasa disebut bawang hutan merupakan tanaman khas Kalimantan Tengah yang sudah dipergunakan masyarakat lokal sebagai obat berbagai jenis penyakit. Penelitian ini bertujuan untuk mengetahui aktivitas senyawa antioksidan dari ekstrak etanol bulbus bawang Dayak yang berasal dari Kota Kotamobagu. Metode penelitian ini adalah eksperimental laboratorium. Awalnya sampel bulbus bawang Dayak diekstraksi maserasi dengan pelarut etanol 96\% kemudian dievaporasi hingga didapatkan ekstrak kental. Sebagai parameter, digunakan metode DPPH (1,1diphenyl-2-picrylhydrazyl) untuk pengujian aktivitas antioksidan sampel pada konsentrasi 50, 60, 70, 80 dan $90 \mathrm{mg} / \mathrm{L}$ dan sebagai standar pembanding digunakan Vitamin $\mathrm{C}$ dengan konsentrasi 2, 4, 6, 8 dan $10 \mathrm{mg} / \mathrm{L}$. Hasil penelitian yang didapat menunjukkan aktivitas antioksidan pada ekstrak etanol bulbus bawang Dayak dengan nilai $\mathrm{IC}_{50}$ sebesar $41,46 \mathrm{mg} / \mathrm{L}$ dan pada vitamin $\mathrm{C}$ nilai $\mathrm{IC}_{50}$ sebesar $1,04 \mathrm{mg} / \mathrm{L}$. Berdasarkan hasil tersebut dapat disimpulkan bahwa ekstrak etanol bulbus bawang Dayak memiliki aktivitas antioksidan yang sangat kuat.
\end{abstract}

Kata kunci: Bulbus Bawang Dayak, Aktivitas, Antioksidan, DPPH 


\section{PENDAHULUAN}

Radikal bebas adalah suatu atom atau molekul yang mempunyai elektron tidak berpasangan. Elektron tidak berpasangan tersebut menyebabkan radikal bebas sangat reaktif yang kemudian akan menangkap atau mengambil elektron dari senyawa lain seperti protein, lipid, karbohidrat, dan DNA untuk menetralkan diri (Liochev, 2013).

Reaksi radikal bebas tersebut dapat terhambat dengan adanya senyawa antioksidan. Antioksidan merupakan senyawa kimia yang dapat menyumbangkan satu atau lebih elektron kepada radikal bebas sehingga penggunaan senyawa antioksidan berkembang dengan pesat, baik untuk makanan maupun pengobatan (Jacob dan Burri, 1996). Berbagai tanaman maupun obat sintesis dapat berperan sebagai antioksidan, antara lain bawang-bawangan, spirulina dan $\mathrm{N}$-asetil sistein (NAC) (Werdhasari, 2014).

Bawang Dayak merupakan tanaman khas Kalimantan Tengah, secara empiris bawang Dayak sudah dipergunakan masyarakat lokal sebagai obat berbagai jenis penyakit seperti kanker payudara, penurun tekanan darah tinggi, penyakit kencing manis, menurunkan kolesterol, obat untuk bisul, kanker usus, mencegah stroke dan mengurangi sakit perut setelah melahirkan. Selain itu, daun tanaman ini juga dapat digunakan sebagai pelancar air susu ibu (Galingging, 2009).

Penelitian uji kandungan kimia pada ekstrak bawang dayak oleh Sharon et al (2013) menyatakan adanya senyawa alkaloid, flavonoid, tanin, fenolat, steroid dan saponin. Hasil tersebut menunjukkan bahwa ekstrak bawang dayak memiliki senyawa antioksidan yaitu flavonoid, tanin dan fenolat. Pada pengujian senyawa fitokimia pada bawang dayak yang dilakukan oleh Kuntorini (2013), selain terdapat senyawa naftokuinon, juga terdeteksi senyawa flavonoid. Kelompok flavonoid mempunyai kemampuan untuk bertransformasi menghasilkan senyawasenyawa yang mempunyai aktivitas antioksidan yang tinggi.

Berdasarkan data tersebut peneliti bermaksud untuk menguji potensi aktivitas antioksidan dari sampel ekstrak etanol bulbus bawang dayak (Eleutherine americana Merr) yang diambil dari Kota Kotamobagu dengan menggunakan metode DPPH (1,1-diphenyl-2picrylhydrazyl).

\section{METODOLOGI PENELITIAN \\ Waktu dan Tempat Penelitian}

Penelitian ini dilaksanakan pada bulan November 2019 sampai bulan Juli 2020 di laboratorium Farmasi Lanjut, Program Studi Farmasi, Fakultas Matematika dan Ilmu Pengetahuan Alam, Universitas Sam Ratulangi.

\section{Bentuk Penelitian}

Bentuk dari penelitian ini ialah penelitian eksperimental laboratorium dengan melakukan pengujian aktivitas antioksidan menggunakan metode DPPH (1,1-Diphenyl-2-Picrylhydrazyl) terhadap ekstrak etanol bulbus bawang dayak (Eleutherine americana Merr) yang diambil dari Kota Kotamobagu.

\section{Alat dan Bahan \\ Alat}

Alat yang digunakan dalam penelitian ini ialah ayakan mesh 100 , kertas saring, pipet tetes, mikropipet, vortex $\left(\right.$ Benchmark $^{\circledR}$ ), aluminium foil, timbangan analitik (AE Adam $\left.^{\circledR}\right)$, batang pengaduk, blender $\left(\right.$ Miyako $\left.^{\circledR}\right)$, spatula, corong, oven (Ecocel MMM Group ${ }^{\circledR}$ ), Spektrofotometer UV-Vis dan alat-alat gelas (Iwaki ST Pyrex ${ }^{\circledR}$ ).

\section{Bahan}

Bahan yang digunakan dalam penelitian ini ialah sampel bulbus bawang dayak (Eleutherine americana Merr.), etanol 96\%, Vitamin C p.a $\left(\right.$ EMSURE $\left.^{\circledR}\right)$, dan serbuk DPPH (1,1-diphenyl-2-picrylhydrazyl) (Sigma-Aldrich $\left.{ }^{\circledR}\right)$.

\section{Prosedur Penelitian \\ Preparasi Sampel}

Bagian umbi dari bawang dayak yang digunakan adalah bulbus yang berukuran $2 \mathrm{~cm}-8$ $\mathrm{cm}$, tidak terlalu muda dan tidak terlalu tua. Dikumpul, dicuci di bawah air mengalir hingga bersih lalu diiris tipis-tipis kemudian di keringkan dalam suhu ruangan. Setelah kering, sampel diblender hingga menjadi serbuk kemudian diayak dengan menggunakan ayakan mesh 100 dan dimasukkan dalam wadah tertutup.

\section{Ekstraksi}

Serbuk sampel bulbus bawang dayak ditimbang sebanyak $500 \mathrm{~g}$, diekstraksi secara maserasi menggunakan pelarut etanol $96 \%$ sebanyak $2500 \mathrm{~mL}$ hingga terendam sempurna. Proses ekstraksi maserasi dilakukan dengan menggunakan wadah yang ditutupi dengan aluminium foil dan disimpan pada tempat yang 
terlindung dari sinar matahari selama 5 hari sambil sesekali diaduk. Remaserasi dilakukan sebanyak 2 kali dengan pelarut etanol $96 \%$ sebanyak $1500 \mathrm{~mL}$ selama masing-masing 3 hari. Filtrat etanol $96 \%$ yang diperoleh kemudian dikumpulkan dan diuapkan dengan oven hingga diperoleh ekstrak kental bulbus Bawang Dayak. Ekstrak kental tersebut ditimbang dengan menggunakan timbangan analitik kemudian disimpan dalam wadah gelas yang tertutup untuk digunakan dalam pengujian.

\section{Pembuatan Larutan Stok}

Sebanyak $100 \mathrm{mg}$ ekstrak etanol bulbus bawang dayak dilarutkan didalam etanol 96\% 100 $\mathrm{mL}$ (Konsentrasi $1000 \mathrm{ppm}$ ). Dengan masingmasing konsentrasi $90 \mathrm{mg} / \mathrm{L}, 80 \mathrm{mg} / \mathrm{L}, 70 \mathrm{mg} / \mathrm{L}$, $60 \mathrm{mg} / \mathrm{L}$, dan $50 \mathrm{mg} / \mathrm{L}$. Hasil dari konsentrasi dicukupkan sampai tanda batas $(10 \mathrm{~mL})$ kemudian larutan dipindahkan ke dalam tabung reaksi dan ditutup dengan menggunakan aluminium foil untuk digunakan pada perlakuan selanjutnya.

\section{Pembuatan Larutan DPPH}

Sebanyak $4 \mathrm{mg}$ serbuk DPPH ditimbang dilarutkan dalam etanol $96 \%$ sebanyak $100 \mathrm{~mL}$. Selanjutnya larutan stok DPPH dilakukan pengujian kontrol, diuji pada spektrofotometri $\mathrm{UV}-\mathrm{Vis}$ dengan panjang gelombang antara 400$800 \mathrm{~nm}$.

\section{Pembuatan dan Pengujian Larutan Vitamin C}

Vitamin C p.a digunakan sebagai kontrol pembanding. Vitamin $\mathrm{C}$ ditimbang sebanyak 10 mg dan dilarutkan dalam etanol 96\% sebanyak 10 $\mathrm{mL}$ (konsentrasi $1000 \mathrm{ppm}$ ) kemudian dibuat larutan stok dengan konsentrasi $2 \mathrm{mg} / \mathrm{L}, 4 \mathrm{mg} / \mathrm{L}, 6$ $\mathrm{mg} / \mathrm{L}, \quad 8 \mathrm{mg} / \mathrm{L}$ dan $10 \mathrm{mg} / \mathrm{L}$ masing-masing larutan dicukupkan dengan etanol sampai tanda batas $(10 \mathrm{~mL})$.

Pengujian dilakukan dengan masingmasing konsentrasi dipipet $2 \mathrm{~mL}$ dan ditambahkan larutan DPPH $2 \mathrm{~mL}$, divorteks selama 15 detik dan diinkubasi selama 30 menit pada suhu $37^{\circ} \mathrm{C}$. Larutan kontrol Vitamin $C$ p.a diuji pada spektrofotometer UV-Vis dengan panjang gelombang $517 \mathrm{~nm}$.

\section{Pengujian Aktivitas Antioksidan dengan Metode DPPH (1,1-Diphenyl-2-Picrylhydrazyl)}

Pengujian dilakukan dengan mengambil sebanyak $2 \mathrm{~mL}$ ekstrak etanol bulbus Bawang Dayak dengan konsentrasi $50 \mathrm{mg} / \mathrm{L}, 60 \mathrm{mg} / \mathrm{L}, 70$ $\mathrm{mg} / \mathrm{L}, \quad 80 \mathrm{mg} / \mathrm{L}$, dan $90 \mathrm{mg} / \mathrm{L}$ ditambahkan masing-masing $2 \mathrm{~mL}$ larutan DPPH dan divorteks selama 15 detik. Berubahnya warna dari ungu menjadi warna kuning pucat menunjukkan efisiensi penangkal radikal bebas. Larutan yang sudah dihomogenkan di inkubasi selama 30 menit pada tempat gelap dengan suhu $37{ }^{\circ} \mathrm{C}$. setelah diinkubasi, absorbansi larutan tersebut diukur terhadap larutan kontrol pada panjang gelombang $517 \mathrm{~nm}$ menggunakan spektroforometri UV-Vis. Nilai presentasi inhibisinya kemudian dihitung dengan rumus berikut:

$$
\% \text { Inhibisi }=\frac{\text { A kontrol }- \text { A sampel }}{A \text { kontrol }} \times 100 \%
$$

Keterangan:

A kontrol = Absorbansi tidak mengandung sampel A sampel $=$ Absorbansi ekstrak

\section{Penentuan Nilai $\mathrm{IC}_{50}$ (Inhibitory Concentration)}

Konsentrasi sampel dan persen inhibisi yang diperoleh diplot masing-masing pada sumbu $\mathrm{x}$ dan $\mathrm{y}$ pada persamaan regresi linear:

$$
y=a x+b
$$

Keterangan:

$\mathrm{y}=$ Variabel terikat

$\mathrm{x}=$ Variabel bebas

$\mathrm{a}=$ Intersep/konstanta

$\mathrm{b}=$ Koefisien regresi/slop

Persamaan tersebut digunakan untuk menentukan nilai $\mathrm{IC}_{50}$ dari masing-masing sampel dinyatakan dengan nilai y sebesar 50 dan nilai $\mathrm{x}$ yang akan diperoleh sebagai $\mathrm{IC}_{50}$. Nilai $\mathrm{IC}_{50}$ didefinisikan sebagai besarnya nilai konsentrasi senyawa uji yang dapat mengikat radikal bebas sebanyak 50\%. Semakin kecil nilai $\mathrm{IC}_{50}$ maka aktivitas pengikatan radikal bebas semakin tinggi (Molyneux, 2004).

\section{HASIL DAN PEMBAHASAN Preparasi Sampel}

Pada penelitian ini sampel yang digunakan adalah bagian umbi dari tanaman Bawang Dayak yang diambil di Kelurahan Mongkonai, Kota Kotamobagu, Provinsi Sulawesi Utara.

Umbi bawang dayak yang diambil, dicuci terlebih dahulu kemudian diris tipis-tipis dan dikeringkan dalam suhu ruangan. Selanjutnya sampel diserbukkan dengan menggunakan blender 
dan diayak dengan ayakan mesh 100. Proses pencucian sampel bertujuan untuk membersihkan kotoran-kotoran atau benda asing yang menempel pada sampel. Proses pengeringan bertujuan untuk menurunkan kadar air sehingga bahan tidak mudah ditumbuhi bakteri dan mempermudah dalam proses pengolahan selanjutnya (Gunawan dan Mulyani, 2004). Proses penyerbukan bertujuan untuk meningkatkan luas permukaan bahan, sehingga senyawa kimia dalam tanaman dapat ditarik secara optimal (Voight, 1995). Proses pengayakan bertujuan untuk menyeragamkan ukuran serbuk dari sampel sehingga partikel yang didapatkan tidak mempengaruhi hasil tahapan selanjutnya (Lachman et al., 1994).

\section{Determinasi}

Determinasi penelitian ini dilakukan di Laboratorium Biologi Dasar Jurusan Biologi Fakultas Matematika dan Ilmu Pengetahuan Alam Universitas Sam Ratulangi dan menunjukan bahwa berdasarkan hasil determinasi tanaman yang digunakan adalah Eleutherine americana Merr. (Tanaman Bawang Hutan).

\section{Ekstraksi}

Proses ekstraksi sampel umbi bawang dayak dilakukan dengan metode ekstraksi maserasi, yang merupakan suatu metode sederhana untuk penyarian ekstrak dengan melakukan perendaman menggunakan pelarut organik dan dilakukan pada suhu ruang (Koirewoa et al., 2012). Ekstraksi menggunakan pelarut etanol $96 \%$ karena etanol merupakan pelarut bersifat universal yang dapat digunakan untuk mengekstrak komponen polar suatu bahan alam (Santana et al., 2009). Pada ekstraksi ini dilakukan maserasi selama 5 x 24 jam sambil sesekali diaduk dan remaserasi dilakukan sebanyak dua kali selama 3 x 24 jam, hal ini dilakukan agar dapat menarik senyawa yang lebih banyak (Fauzana, 2010). Setelah maserasi didapatkan filtrat sebanyak tiga filtrat kemudian dicampur menjadi satu dan diperoleh filtrat sebanyak 5,5 L. Filtrat tersebut kemudian dievaporasi menggunakan oven dengan suhu $40^{\circ} \mathrm{C}$ selama 1 x 24 jam. Evaporasi merupakan suatu proses penguapan sebagian dari pelarut sehingga didapatkan larutan zat cair pekat yang berkonsentrasi tinggi (Praptiningsih, 1999). Setelah dievaporasi didapatkan ekstrak kental dengan pelarut etanol $96 \%$ sebanyak 26,27 gr kemudian hasil dari ektraksi tersebut digunakan untuk tahapan uji antioksidan.

\section{Uji Aktivitas Antioksidan Dengan Metode DPPH}

Penentuan nilai aktivitas antioksidan pada penelitian ini menggunakan metode DPPH. Pemilihan metode ini karena metode ini merupakan metode yang sederhana, mudah, cepat dan peka serta hanya memerlukan sedikit sampel untuk pengujian aktivitas antioksidan (Hanani et al., 2005). Menurut Molyneux (2004), prinsip dari metode uji antioksidan ini adalah pengukuran aktivitas antioksidan secara kuantitatif atau dengan cara melakukan pengukuran penangkapan radikal DPPH oleh suatu senyawa yang memiliki aktivitas antioksidan dan kemudian absorbansinya dilihat menggunakan spektrofotometri UV-Vis pada panjang gelombang $517 \mathrm{~nm}$ sehingga diketahui nilai aktivitas perendaman radikal bebas yang dinyatakan dengan nilai $\mathrm{IC}_{50}$. Nilai $\mathrm{IC}_{50}$ didefinisikan sebagai besarnya nilai konsentrasi senyawa uji yang dapat mengikat radikal bebas sebanyak $50 \%$. Semakin kecil nilai $\mathrm{IC}_{50}$ maka aktivitas pengikatan radikal bebas semakin tinggi. antioksidan dikatakan bersifat sangat kuat jika nilai $\mathrm{IC}_{50}$ kurang dari $50 \mathrm{ppm}$, bersifat kuat jika nilai $\mathrm{IC}_{50} 50 \mathrm{ppm}-100 \mathrm{ppm}$, bersifat sedang jika nilai $\mathrm{IC}_{50} 100 \mathrm{ppm}-150 \mathrm{ppm}$ dan bersifat lemah jika nilai $\mathrm{IC}_{50}$ bernilai $150 \mathrm{ppm}-200 \mathrm{ppm}$. Hasil dari pengujian aktivitas antioksidan dengan metode DPPH dapat dilihat pada Tabel 1. 
Tabel 1. Hasil pengujian aktivitas antioksidan dengan metode DPPH.

\begin{tabular}{cccccc}
\hline Sampel & $\begin{array}{c}\text { Konsentrasi } \\
(\mathbf{m g} / \mathbf{L})\end{array}$ & $\begin{array}{c}\text { Rata }- \text { rata } \\
\text { absorbansi }\end{array}$ & $\begin{array}{c}\text { Rata }- \text { rata } \% \\
\text { inhibisi }\end{array}$ & $\begin{array}{c}\text { Rata-rata } \pm \text { SD } \\
\text { (Standar } \\
\text { Deviasi })\end{array}$ & $\begin{array}{c}\mathbf{I C}_{\mathbf{5 0}} \\
(\mathbf{m g} / \mathbf{L})\end{array}$ \\
\hline $\begin{array}{c}\text { Ekstrak } \\
\text { Bawang }\end{array}$ & 50 & 0,322 & 54,36 & $54,36 \pm 1,39$ & \\
Dayak & 70 & 0,241 & 65,86 & $65,86 \pm 1,84$ & \\
& 80 & 0,231 & 67,32 & $67,32 \pm 0,37$ & 41,46 \\
& 90 & 0,151 & 78,73 & $78,73 \pm 0,16$ & \\
& 2 & 0,123 & 82,55 & $82,55 \pm 0,22$ & \\
& 4 & 0,316 & 55,21 & $55,21 \pm 0,21$ & \\
Vitamin C & 6 & 0,243 & 65,62 & $65,62 \pm 0,25$ & \\
& 8 & 0,214 & 69,68 & $69,68 \pm 21,91$ & 1,04 \\
& 10 & 0,116 & 83,59 & $83,59 \pm 16,57$ & \\
& & 0,043 & 93,87 & $93,87 \pm 0,57$ &
\end{tabular}

Berdasarkan hasil yang diperoleh pada pengujian DPPH menunjukan bahwa persen inhibisi ekstrak etanol bawang dayak mengalami peningkatan pada konsentrasi $90 \mathrm{mg} / \mathrm{L}$ yaitu sebesar 82,55\%. Untuk kemampuan aktivitas penangkal radikal bebas ekstrak etanol bawang dayak menunjukkan nilai $\mathrm{IC}_{50}$ yang sangat kuat yaitu $41,46 \mathrm{mg} / \mathrm{L}$. Nilai $\mathrm{IC}_{50}$ yang cukup tinggi ini dikarenakan bulbus bawang dayak mengandung beberapa senyawa yang berperan sebagai antioksidan kuat diantaranya yaitu senyawa naftokuinon dan flavonoid. Kelompok flavonoid mempunyai kemampuan untuk bertransformasi menjadi senyawa yang mempunyai aktivitas lebih tinggi sebagai antioksidan. Flavonoid diketahui berperan sebagai antioksidan yang baik karena mempunyai mempunyai sedikitnya dua gugus hidroksil (Kuntorini, 2013).

Hasil reaksi antara pengikatan radikal bebas DPPH dengan senyawa antioksidan pada ekstrak diketahui dengan perubahan warna dari ungu pekat menjadi kuning pucat akibat terjadi resonansi struktur pengikat radikal bebas DPPH. Pengurangan intensitas warna yang terjadi berhubungan dengan jumlah elektron pengikat radikal bebas DPPH yang mengikat atom hidrogen dari senyawa antioksidan. Perubahan warna yang terjadi menunjukkan adanya aktivitas antioksidan yang kuat yang terkandung didalam ekstrak (Najoan et al., 2016). Hasil persen inhibisi sampel dapat dilihat pada gambar 1 dan hasil persen inhibisi Vitamin $\mathrm{C}$ dalam bentuk grafik seperti pada gambar 2 .

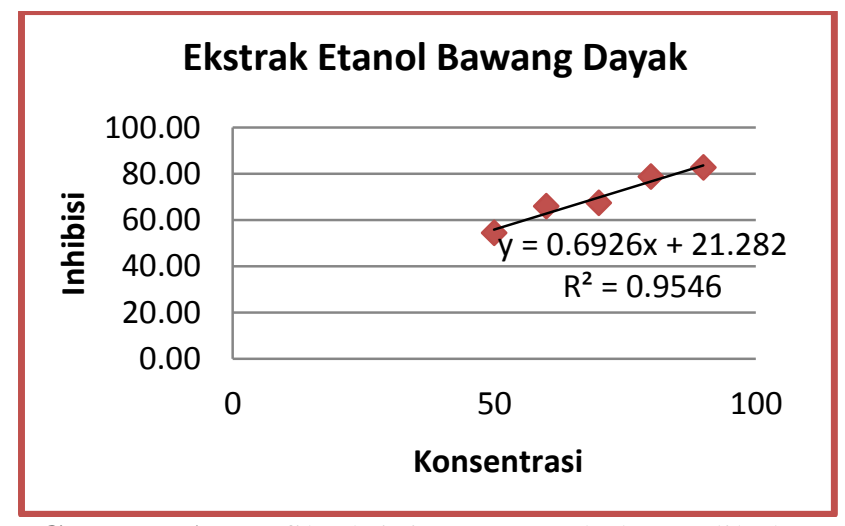

Gambar 1. Grafik aktivitas penangkalan radikal bebas ekstrak etanol sampel.

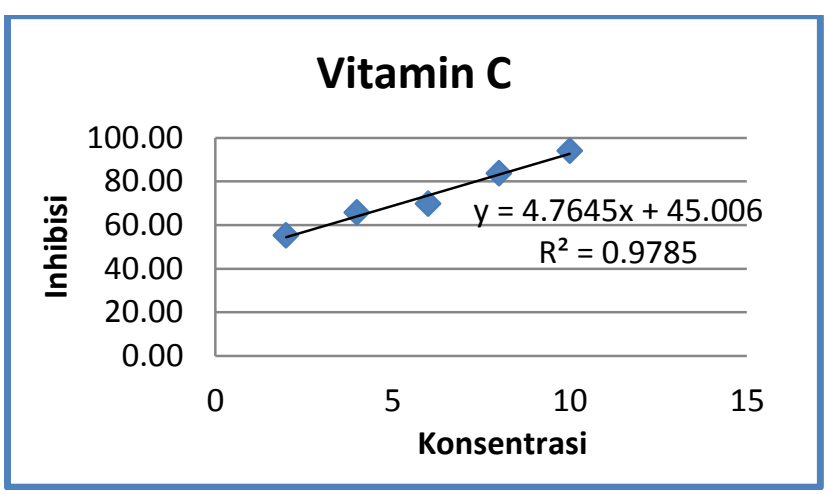

Gambar 2. Grafik aktivitas penangkalan radikal bebas Vitamin C. 
Penggunaan Vitamin $\mathrm{C}$ sebagai pembanding dikarenakan vitamin $\mathrm{C}$ merupakan suatu zat yang mempunyai aktivitas antioksidan yang cukup tinggi. Hal ini dapat dilihat dari hasil pada pengujian dengan DPPH diperoleh persen inhibisi vitamin $\mathrm{C}$ meningkat pada konsentrasi 10 $\mathrm{mg} / \mathrm{L}$ yakni $93.87 \%$. dan nilai $\mathrm{IC}_{50}$ dari vitamin $\mathrm{C}$ yaitu sebesar $1,04 \mathrm{mg} / \mathrm{L}$. Hasil dari ekstrak bawang dayak dan vitamin $\mathrm{C}$ mempunyai aktivitas antioksidan yang bersifat sangat kuat karena nilai $\mathrm{IC}_{50}<50$, dimana diketahui bahwa semakin kecil nilai $\mathrm{IC}_{50}$ maka semakin kuat daya aktivitas antioksidannya tetapi aktivitas antioksidan ekstrak bawang dayak lebih rendah jika dibandingkan dengan vitamin C. Hal ini dikarenakan vitamin $\mathrm{C}$ merupakan senyawa murni, sedangkan ekstrak bawang dayak terdiri dari beberapa campuran senyawa (Pratiwi et al, 2013).

Peningkatan dari persen inhibisi terjadi untuk menandakan bahwa semakin besar konsentrasi dari ekstrak maka semakin besar pula persen inhibisi yang dihasilkan. Hal ini didukung oleh penelitian Hanani et al (2005) yang menyatakan bahwa presentase penghambatan atau persen inhibisi terhadap aktivitas dari radikal bebas akan ikut meningkat seiring dengan meningkatnya konsentrasi.

Menurut Hasil penelitian tentang pengujian aktivitas antioksidan yang lain diantaranya penelitian dilakukan oleh Hidayah et al (2015), pada sampel umbi bawang dayak yang diperoleh dari daerah Sumedang, Kabupaten Sumedang, Provinsi Jawa Barat dengan menggunakan pelarut etanol $70 \%$ nilai $\mathrm{IC}_{50}$ bersifat sangat kuat yaitu sebesar 46,14 ppm.

Penelitian tentang penentuan aktivitas antioksidan ektrak etanol bawang dayak yang dilakukan oleh Kuntorini dan Astuti (2010), pada sampel bawang dayak yang berasal dari Kota Banjarbaru, provinsi Kalimantan Selatan diuji dengan menggunakan metode DPPH memiliki aktivitas antioksidan yang juga sangat kuat yaitu dengan nilai $\mathrm{IC}_{50}$ sebesar 25,33 ppm.

\section{KESIMPULAN}

Berdasarkan hasil penelitian yang dilakukan maka dapat disimpulkan bahwa ekstrak etanol bawang dayak yang berasal dari Kelurahan Mongkonai, Kota Kotamobagu, Provinsi Sulawesi Utara memiliki aktivitas antioksidan yang sangat kuat dengan nilai $\mathrm{IC}_{50}$ sebesar $41,46 \mathrm{mg} / \mathrm{L}$.

\section{SARAN}

Disarankan untuk penelitian selanjutnya untuk melakukan pengujian kandungan senyawa aktif yang terkandung sehingga dapat diketahui lebih spesifik senyawa apa yang berperan sebagai antioksidan pada bawang dayak dan selanjutnya bisa dilakukan penelitian untuk melihat perbandingan antara aktivitas antioksidan pada bawang dayak dari Sulawesi Utara dan dari daerah lain.

\section{DAFTAR PUSTAKA}

Fauzana, D. L. 2010. Perbandingan Metode Maserasi, Remaserasi, Perkolasi dan Reperkolasi Terhadap Rendemen Ekstrak Temulawak (Curcuma xanthorrhiza Roxb). [Skripsi]. Fakultas Teknologi Pertanian IPB, Bogor.

Galingging, R. Y. 2009. Bawang Dayak (Eleutherine palmifolia) Sebagai Tanaman Obat Multifungi. Warta Penelitian dan Pengembangan. 15(3): 2-4.

Gunawan, D dan Mulyani, S. 2004. Ilmu Obat Alam Farmakognosi jilid I. Penebar Swadaya, Jakarta.

Hanani, E., A, Mun'im, R. \& Sekarini. 2005. Identifikasi Senyawa Antioksidan Dalam Spons Calispongia sp dari Kepulauan Seribu. Majalah Ilmu Kefarmasian. 2(3): 127-133.

Hidayah, A. S., Mulkiya, K \& Purwanti, L. 2015. Uji Aktivitas Antioksidan Umbi Bawang Dayak (Eleutherine bulbosa Merr.). Prosiding SpeSIA Unisba. 1(2): 397-404.

Jacob R. A and Burri B. J. 1996. The Oxidative Damage and Defense. The American Journal of Clinical Nutrition. 63(6): 986990.

Koirewoa, Y. A., Fatimawali, \& Wiyono, W. I. 2012. Isolasi dan Identifikasi Senyawa Flavonoid Dalam Daun Beluntas (Pluchea indica L.). Pharmacon. 1(1): 47-52.

Kuntorini E. M. 2013. Kemampuan Antioksidan Bulbus Bawang Dayak (Eleutherine ameriana Merr) Pada Umur Berbeda. Prosiding Semirata FMIPA Universitas Lampung. 1(1): 297-301. 
Kuntorini, E. M. dan Astuti, M. D. 2010. Penentuan Aktivitas Antioksidan Ekstrak Etanol Bulbus Bawang Dayak (Eleutherine americana Merr.). Sains dan Terapan Kimia. 4(1): 15-22.

Lachman, L. Lieberman, H. A., \& Kaning, J. L. 1994. Teori dan Praktek Farmasi Industri II edisi III. Diterjemahkan oleh Suyatmi, S. Universitas Indonesia Press, Jakarta.

Liochev, S. I. 2013. Reactive Oxygen Species and the Free Radical Theory of Aging. Free Radical Biology and Medicine. 60: 1-4.

Molyneux, P. 2004. The Use of The Stable Free Radical Diphenylpicrylhydrazyl (DPPH) for Estimating Antioxidant Activity. Songklanakarin: Journal Science Technologi.26(2): 211-219.

Najoan, J. J., Runtuwene, M. J. R., \& Mewengkang, D. S. 2016. Uji Fitokimia dan Aktivitas Antioksidan Ekstrak Etanol Daun Tiga (Allophylus cobbe L). Pharmacon. 5(1): 266-274.

Praptiningsih, Y. 1999. Buku Ajar Teknologi Pengolahan. FTP Universitas Jember, Jember.
Pratiwi, D., Wahdaningsih, S., \& Isnindar. 2013. Uji Aktivitas Antioksidan Daun Bawang Mekah (Eleutherine americana Merr) Dengan Metode DPPH (2,2-difenil-1pikrilhidrazil). Traditional Medicine Journal. 18(1): 9-16.

Santana, C. M., Z. S. Ferrera, M.E.T. Padron, \& J.J.S. Rodriquez. 2009. Methodologies for The Extraction of Phenolic Compounds from Enviromental Sample: New Approaches. Molecules. 14: 298-320.

Sharon, N., Anam, S., \& Yuliet. 2013. Formulasi Krim Antioksidan Ekstrak Etanol Bawang Hutan (Eleutherine palmifolia L. Merr). Online Jurnal of Natural Science. 2(3): 111-122.

Voight, R. 1995. Buku pelajaran Teknologi Farmasi. Alih bahasa Drs. S. N. Soewandhi. Universitas Gadjah Mada, Yogyakarta.

Werdhasari A. 2014. Peran Antioksidan Bagi Kesehatan. Jurnal Biotek Medisiana Indonesia. 3(2): 59-68. 